\title{
Diagnosis of Creutzfeldt-Jakob disease by measurement of S100 protein in serum: prospective case-control study
}

\author{
Markus Otto,Jens Wiltfang, Ekkehard Schütz, Inga Zerr, Anke Otto, Annette Pfahlberg, \\ Olaf Gefeller, Manfred Uhr, Armin Giese, Thomas Weber, Hans A Kretzschmar, Sigrid Poser
}

\begin{abstract}
Objective: To analyse serum concentrations of brain specific S100 protein in patients with Creutzfeldt-Jakob disease and in controls.

Design: Prospective case-control study.

Setting: National Creutzfeldt-Jakob disease surveillance unit.
\end{abstract}

Subjects: 224 patients referred to the surveillance unit with suspected Creutzfeldt-Jakob disease and 35 control patients without dementia.

Main outcome measure: Serum concentration of S100 protein in patients with Creutzfeldt-Jakob disease, in patients with other diseases causing dementia, and in the control group.

Results: Of the 224 patients with suspected Creutzfeldt-Jakob disease, 65 were classed as definitely having the disease after neuropathological verification, an additional 6 were classed as definitely having the disease as a result of a genetic mutation, 43 as probably having the disease, 36 as possibly having the disease, and 74 patients were classed as having other disease. In the 108 patients classed as definitely or probably having Creutzfeldt-Jakob disease the median serum concentration of S100 was $395 \mathrm{pg} / \mathrm{ml}$ (SD $387 \mathrm{pg} / \mathrm{ml}$ ). This was significantly higher than concentrations found in the 74 patients classed as having other diseases (median 109 pg/ml; SD 177 pg/ml; P = 0.0001). At a cut off point of $213 \mathrm{pg} / \mathrm{ml}$ sensitivity for the diagnosis of the disease was $77.8 \%$ (95\% confidence interval $68.8 \%$ to $85.2 \%)$ and specificity was $81.1 \%$ (70.3\% to $89.3 \%)$. There was a significant difference in survival at different concentrations of S100 in Kaplan-Meier curves $(\mathrm{P}=0.023)$.

Conclusion: Measurement of serum concentrations of $\mathrm{S} 100$ is a valuable tool which can be used more easily than tests on cerebrospinal fluid in the differential diagnosis of Creutzfeldt-Jakob disease. More studies are needed to determine whether serial testing of serum S100 improves diagnostic accuracy.

\section{Introduction}

Creutzfeldt-Jakob disease is a progressive and fatal disorder of the central nervous system; it is a transmissible spongiform encephalopathy. ${ }^{1}$ The incidence of Creutzfeldt-Jakob disease is $0.5-1$ new case per million population. ${ }^{2}$ Clinically, Creutzfeldt-Jakob disease is characterised by rapidly progressing dementia and more than $90 \%$ mortality within one year of onset. ${ }^{1}$ Diagnosis can only be made by neuropathological or immunochemical identification of the pathological isoform of the prion protein in human brain tissue. ${ }^{3}$ The pathological isoform has also been identified in tonsillar tissue at necropsy but this identification has not been used to confirm the diagnosis of CreutzfeldtJakob disease before death. ${ }^{4}$ Diagnosis is usually made clinically ${ }^{5}$ and electroencephalographically. ${ }^{6}$ Diagnosis can be confirmed by biochemical analysis of cerebrospinal fluid which identifies neuron specific enolase, ${ }^{78}$ S100 protein, ${ }^{79}$ tau protein, ${ }^{10}$ and $14-3-3$ protein. ${ }^{11-13}$ However, detection of these proteins in serum has not been useful diagnostically for methodological reasons, such as the detection limits for $\mathrm{S} 100$ and 14-3-3 protein and problems with cross reactions with non-brain specific isoforms. Thus biological confirmation of the clinical diagnosis while the patient is still alive has been hampered by the inability to easily and repeatedly identify biological markers.

At our clinic we use an immunoluminometric method to detect brain specific S100b protein in serum (LIA-mat Sangtec100, Bromma, Sweden). The detection limit of this assay is $20 \mathrm{pg} / \mathrm{ml}$ in serum; earlier assays had detection limits of $0.5 \mathrm{ng} / \mathrm{ml} . .^{79} \mathrm{~S} 100$ is an acidic calcium binding protein which is found as a homodimer or heterodimer of two subunits, $\alpha$ and $\beta$, with molecular weights of $10.4 \mathrm{kD}$ and $10.5 \mathrm{kD}$, respectively. In brain tissue $\mathrm{S} 100$ is found mainly in glial cells. ${ }^{14}{ }^{15}$ Raised concentrations of S100 in serum and cerebrospinal fluid have been reported after major ${ }^{16}$ and minor head injury. ${ }^{17}$ In these cases $\mathrm{S} 100$ concentrations decreased rapidly as the protein was eliminated by the kidneys; the estimated biological half life of S100 is 2 hours. ${ }^{18}$ S100 was originally thought to be a marker of brain destruction in acute disease, but now it is thought to be a marker of activated astroglia, which is seen at all stages of Creutzfeldt-Jakob disease. ${ }^{3}$ We investigated the diagnostic potential of measuring serum concentrations of $\mathrm{S} 100$ in the differential diagnosis of Creutzfeldt-Jakob disease.

\section{Subjects and methods}

Since June 1993 suspected cases of Creutzfeldt-Jakob disease in Germany have been reported to the
See editorial by Pocchiari and 593

Neurologische Klinik und Poliklinik, Georg-AugustUniversität

Göttingen,

Robert-Koch

Strasse 40, D-37075 Göttingen,

Germany

Markus Otto, group leader, laboratory diagnosis of $C J D$ Inga Zerr, research fellow Anke Otto, research fellow Sigrid Poser, head, epidemiology and early diagnosis of CJD

Psychiatrische Klinik und Poliklinik, Georg-AugustUniversität Göttingen Jens Wiltfang, senior research fellow

Abteilung Klinische Chemie, Georg-August-

Universität

Göttingen

Ekkehard Schütz,

research fellow

Abteilung

Medizinische

Statistik,

Georg-August-

Universität

Göttingen

Annette Pfahlberg, statistician

Olaf Gefeller, associate professor of medical statistics

continued over

BMJ 1998;316:577-82 
Max-Planck Institut für Psychiatrie,

Kraepelinstrasse 10, D-80804 Munich,

Germany

Manfred Uhr,

research fellow,

Institut für

Neuropathologie,

Georg-August-

Universität

Göttingen

Armin Giese,

research fellow

Hans A

Kretzschmar,

head, department of

neuropathology

Neurologische

Abteilung

Marienkrankenhaus

Hamburg,

Alfredstrasse 9,

D-22087 Hamburg,

Germany

Thomas Weber,

head, department of

neurology

Correspondence to:

Dr Otto

100634.133@

compuserve.com
Creutzfeldt-Jakob disease surveillance unit at the department of neurology at Georg August University in Göttingen. Each patient who is reported to the unit is visited by a research physician and examined using a standardised $\operatorname{protocol}^{19}$; a control patient without dementia was examined at the same time. All controls were matched for age and sex with a patient with suspected Creutzfeldt-Jakob disease. Serum samples were obtained from some of the controls.

Between June 1993 and December 1995, 300 patients suspected of having Creutzfeldt-Jakob disease were seen by a member of the research team. Serum samples were obtained from 224 patients; only these patients are included in the present paper. We also analysed serum samples from the first 35 control patients seen.

All suspected cases of Creutzfeldt-Jakob disease were classed as definitely having the disease, probably having the disease, possibly having the disease, or having other disease according to clinical criteria described elsewhere. ${ }^{50}$ All patients had cranial computed tomography or magnetic resonance imaging of the brain, or both, to exclude ischaemic stroke, haemorrhages, or space occupying lesions as a cause of illness.

Patients were classed as probably having Creutzfeldt-Jakob disease if they had rapidly progressive dementia of less than 2 years' duration and periodic sharp wave complexes on electroencephalography. They also had to have any two of the following symptoms: myoclonus; visual or cerebellar symptoms, or both; pyramidal or extrapyramidal signs, or both; or akinetic mutism. Patients who fulfilled the criteria for probably having the disease but did not have any abnormalities on electroencephalography were classed as possibly having the disease. Patients who did not fulfil the criteria for either possibly or probably having the disease were classed as having other disease. Patients who had an identified pathological isoform of the prion protein in brain tissue on immunohistochemical analysis were classed as definitely having the disease. ${ }^{3}$

\section{Sample collection and analysis}

Serum samples were collected by a research physician and stored at $-80^{\circ} \mathrm{C}$ within 24 hours.

In 6 out of the 116 patients who were tested a mutation was detected in the prion protein gene. ${ }^{21}$ Altogether 151 of the 224 patients had died by 1 May 1997. A neuropathological examination was done on 83 patients according to standard protocols. ${ }^{3}$

Serum concentration of S100 protein was measured using the immunoluminometric assay kit already described. This test measures the $\beta$ subunit of the $S 100$ protein. An intra-assay coefficient of variation of $5.5 \%$ and an interassay coefficient of variation of $10.1 \%$ were defined at $280 \mathrm{pg} / \mathrm{ml}$. All samples were tested twice and the mean values were used for additional calculations. A coefficient of variation of $10 \%$ was accepted. Serum concentrations below $20 \mathrm{pg} / \mathrm{ml}$ were reported as $0 \mathrm{pg} / \mathrm{ml}$.

\section{Statistical analysis}

Standard measures of test validity including sensitivity, specificity, and predictive values with 95\% confidence intervals were calculated. ${ }^{22}$ The optimal cut off point for dichotomising serum concentrations of S100 was selected to maximise the Youden index. ${ }^{23}$ The receiver operating characteristics curve was calculated to show the variability of sensitivity and specificity for cut off points of different concentrations of S100 protein, which was measured as a continuous variable. ${ }^{24}$

The comparison of the distribution of S100 concentrations between subgroups in the study population was based on non-parametric rank tests (for comparisons between two groups the Wilcoxon signed rank test and Mann-Whitney U test were used; for matched groups the Wilcoxon signed rank test was used; for the three groups described as definitely or probably having the disease, possibly having the disease, and having other disease the Kruskal-Wallis test was used). Additionally, Kaplan-Meier curves were calculated to show the probability of survival for three subgroups of patients classed as definitely or probably having the disease; the subgroups were divided according to serum concentration of $\mathrm{S} 100(<300 \mathrm{pg} / \mathrm{ml}$, $300-600 \mathrm{pg} / \mathrm{ml},>600 \mathrm{pg} / \mathrm{ml})$. Differences between the estimated survival curves were statistically evaluated using the log rank test.

\section{Results}

Serum concentrations of S100 protein were determined for 224 patients who were suspected of having Creutzfeldt-Jakob disease and for 35 control patients without dementia. Final diagnoses for the 224 patients included 65 patients neuropathologically classed as definitely having the disease, an additional 6 classed as definitely having the disease as a result of a genetic mutation, 43 classed as probably having the disease, 36 as possibly having the disease, and 74 as having other disease. The most recent clinical information including results of neuropathological examination, if available, was used to divide the patients into groups. The distribution of patients by clinical diagnosis and their final classification is shown in table 1. Final diagnosis for

Table 1 Distribution of 224 patients with suspected Creutzfeldt-Jakob disease by initial diagnosis and final diagnosis. Values are numbers of patients

\begin{tabular}{llccc} 
& \multicolumn{4}{c}{ Final diagnosis } \\
\cline { 2 - 5 } Initial diagnosis & $\begin{array}{c}\text { Definite } \\
\text { CJD }\end{array}$ & $\begin{array}{c}\text { Probable } \\
\text { CJD }\end{array}$ & $\begin{array}{c}\text { Possible } \\
\text { CJD }\end{array}$ & $\begin{array}{c}\text { Other } \\
\text { disease }\end{array}$ \\
\hline Probable CJD $(\mathrm{n}=92)$ & $48^{*}$ & 42 & 0 & 2 \\
\hline Possible CJD $(\mathrm{n}=62)$ & $20 \dagger$ & 0 & 36 & 6 \\
\hline Other disease $(\mathrm{n}=70)$ & $3 \ddagger$ & 1 & 0 & 66 \\
\hline
\end{tabular}

CJD=Creutzfeldt-Jakob disease.

*Includes two patients with a genetic basis to their disease.

tIncludes three patients with a genetic basis to their disease. łncludes one patient whose disease had a genetic basis.

Table 2 Distribution of 224 patients with suspected CreutzfeldtJakob disease and 35 controls without dementia by age and sex

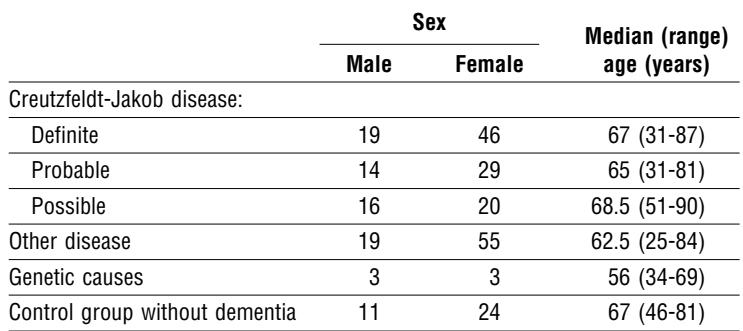


Table 3 Clinical and electroencephalographic signs and symptoms of 224 patients with suspected Creutzfeldt-Jakob disease at time of entry into the study. Values are numbers of patients (percentages)

\begin{tabular}{lccc} 
Symptoms & $\begin{array}{c}\text { Definite or } \\
\text { probable CJD } \\
(\mathbf{n = 1 0 8 )}\end{array}$ & $\begin{array}{c}\text { Possible } \\
\text { CJD } \\
(\mathbf{n}=\mathbf{3 6})\end{array}$ & $\begin{array}{c}\text { Other } \\
\text { disease } \\
(\mathbf{n}=\mathbf{7 4 )}\end{array}$ \\
\hline $\begin{array}{l}\text { Rapidly progressive dementia of } \\
<2 \text { years' duration }\end{array}$ & $101(94)$ & $36(100)$ & $32(43)$ \\
$\begin{array}{l}\text { Periodic sharp wave complexes on } \\
\text { electroencephalography }\end{array}$ & $89(82)$ & 0 & $2(3)$ \\
\hline $\begin{array}{l}\text { Myoclonus } \\
\text { Visual or cerebellar symptoms, or both }\end{array}$ & $93(86)$ & $26(72)$ & $26(35)$ \\
\hline Pyramidal or extrapyramidal signs, or both & $72(67)$ & $34(86)$ & $31(42)$ \\
\hline Akinetic mutism & $62(57)$ & $12(33)$ & $38(51)$ \\
\hline
\end{tabular}

CJD=Creutzfeldt-Jakob disease.

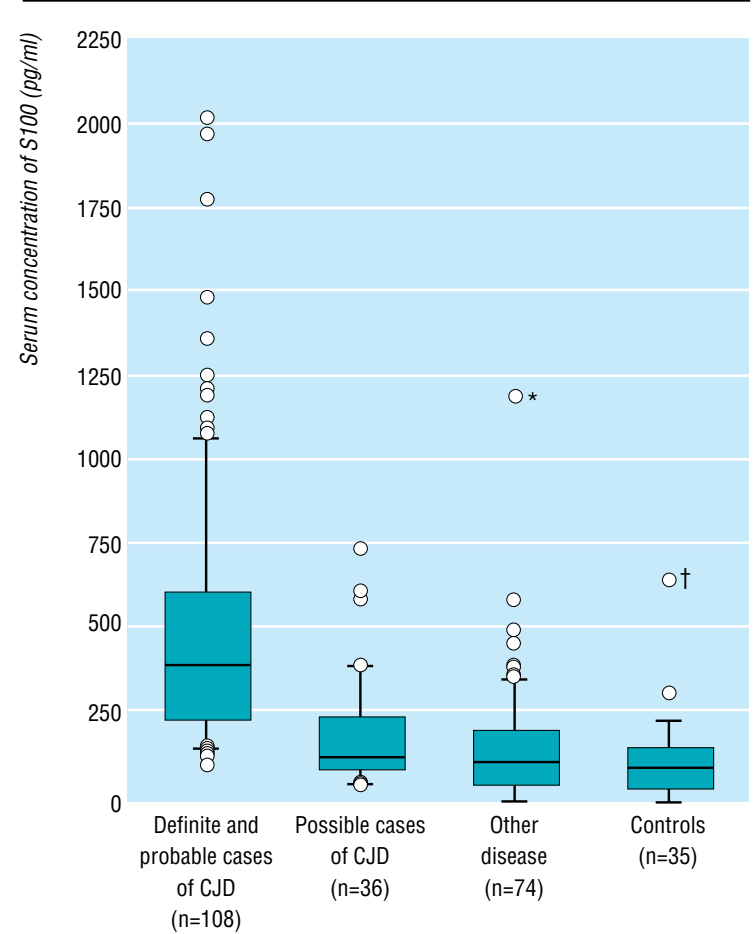

Fig 1 Serum concentrations of S100 protein by final diagnosis. 10th 25th, 75th, and 90th percentiles are shown. CJD=Creutzfeldt-Jakob disease; *Patient with meningoencephalitis; †Patient with amyotrophic lateral sclerosis

patients classed as having other disease was obtained either at necropsy or by follow up reports from hospitals. The distribution of patients and controls by age and sex is shown in table 2 .

Of the cases of Creutzfeldt-Jakob disease with a genetic basis two had fatal familial insomnia with a mutation at D178N, one had Gerstmann-SträusslerScheinker disease with a mutation at P102L, two patients had a mutation at V210I, and one had an insert mutation $(9 * 24)$. The patients with fatal familial insomnia and the patient with Gerstmann-SträusslerScheinker had all been classed clinically as possibly having Creutzfeldt-Jakob disease. Initially, the patients with the mutation at V210I had been classed as probably having the disease; the patient with the insert mutation had initially been classed as having other disease.

For further analysis those classed as definitely and those classed as probably having the disease were grouped together since almost all of those classed as probably having the disease became definite cases after necropsy. Patients' clinical symptoms at the time of entry into the study are shown in table 3 .

The serum concentrations of S100 protein in the combined group of patients classed as definitely or probably having the disease ranged from $95 \mathrm{pg} / \mathrm{ml}$ to $2016 \mathrm{pg} / \mathrm{ml}$ (median $395 \mathrm{pg} / \mathrm{ml}$ ) (fig 1). Among those who definitely had the disease serum concentrations ranged from $120 \mathrm{pg} / \mathrm{ml}$ to $2016 \mathrm{pg} / \mathrm{ml}$ (median $439 \mathrm{pg} / \mathrm{ml}$ ); among those who probably had the disease concentrations ranged from $95 \mathrm{pg} / \mathrm{ml}$ to $1199 \mathrm{pg} / \mathrm{ml}$ (median $347 \mathrm{pg} / \mathrm{ml}$ ). For those classed as possibly having the disease concentrations ranged from $<20 \mathrm{pg} / \mathrm{ml}$ to $742 \mathrm{pg} / \mathrm{ml}$ (median $118 \mathrm{pg} / \mathrm{ml}$ ). Among those classed as having other diseases concentrations ranged from $<20 \mathrm{pg} / \mathrm{ml}$ to $1198 \mathrm{pg} / \mathrm{ml}$ (median $109 \mathrm{pg} / \mathrm{ml}$ ). Concentrations in the control group ranged from $<20 \mathrm{pg} / \mathrm{ml}$ to $657 \mathrm{pg} / \mathrm{ml}$ (median $97 \mathrm{pg} / \mathrm{ml}$ ). Additional information on serum concentrations of S100 in those classed as having other diseases is given in table 4 with the final diagnoses. Diagnoses and concentrations are given for patients in the control group without dementia in table 5 .

Differences between the three groups (the combined group of those with definite or probable disease, those with possible disease, and those with other disease) were significant $(\mathrm{P}=0.0001)$. There was also a significant difference between matched pairs of the combined group (those with definite or probable disease) and the controls $(\mathrm{n}=35)(\mathrm{P}=0.0001)$. There was no significant difference when the group of those classed as possibly having the disease was compared with those classed as having other disease $(\mathrm{P}=0.1)$.

Table 4 Median serum concentration of $S 100$ protein in patients classed as having other disease $(n=74)$. No of patients whose diseases were verified neuropathologically are given in parentheses

\begin{tabular}{lcc} 
Diagnosis & $\begin{array}{c}\text { No of } \\
\text { patients }\end{array}$ & $\begin{array}{c}\text { Median (range) } \\
\mathbf{( p g / m I )}\end{array}$ \\
\hline Alzheimer's disease & $16(5)$ & $100.5(0-465)$ \\
\hline Parkinson's disease & 11 & $91(24-248)$ \\
\hline Multi-infarct dementia & $8(2)$ & $393(0-393)$ \\
\hline Progressive dementia & 5 & $529(63-592)$ \\
\hline Amyotrophic lateral sclerosis & $4(3)$ & $179(0-179)$ \\
\hline Chronic encephalopathy & 3 & $47(58-105)$ \\
\hline Hypoxic brain damage & $3(1)$ & $249(40-289)$ \\
\hline Meningoencephalitis & $2(1)$ & $(504-1198)$ \\
\hline Multiple sclerosis & $2(1)$ & $(142-372)$ \\
\hline Pick's disease & 2 & $(20-115)$ \\
\hline Wernicke's disease & 2 & $(53-360)$ \\
\hline Epilepsy & 2 & $(29-36)$ \\
\hline Depression & 2 & $(64-112)$ \\
\hline Central pontine myelinolysis & 1 & 57 \\
\hline Subdural haematoma & 1 & 84 \\
\hline Psychosis & 1 & 0 \\
\hline Spinocerebellar ataxia & 1 & 28 \\
\hline Post-traumatic brain damage & 1 & 130 \\
\hline Cerebral amyloid angiopathy & 1 & 106 \\
\hline Hyperparathyroidism & 1 & 142 \\
\hline Intoxication & 1 & 209 \\
\hline Huntington's disease & 1 & 59 \\
\hline B cell lymphoma & 1 & 207 \\
\hline Hashimoto's disease & 167 \\
\hline Paraneoplastic syndrome & 1 & 0 \\
\hline & 1 & \\
\hline
\end{tabular}


Table 5 Serum concentrations of $\mathbf{S 1 0 0}$ protein and final diagnosis in controls without dementia $(n=35)$

\begin{tabular}{lcc} 
Diagnosis & $\begin{array}{c}\text { No of } \\
\text { patients }\end{array}$ & $\begin{array}{c}\text { Median (range) } \\
\mathbf{( p g / m l )}\end{array}$ \\
\hline Transient ischaemic attack & 6 & $96.5(0-188)$ \\
\hline Lower back pain & 6 & $24.5(0-318)$ \\
\hline Depression & 4 & $72(0-178)$ \\
\hline Brain tumour & 4 & $170.5(73-240)$ \\
\hline Polyneuropathy & 4 & $47.5(0-108)$ \\
\hline Unknown & 2 & $(0-124)$ \\
\hline Borreliosis & 1 & 58 \\
\hline Parkinson's disease & 1 & 125 \\
\hline Intracranial bleeding & 1 & 101 \\
\hline Lung oedema & 1 & 146 \\
\hline Psychosis & 1 & 78 \\
\hline Amyotrophic lateral sclerosis & 1 & 657 \\
\hline Guillain-Barré syndrome & 1 & 187 \\
\hline Colon cancer & 1 & 155 \\
\hline Fracture of the spine & 1 & 316 \\
\hline
\end{tabular}

There was a significant difference when the combined group (those with definite or probable disease) was compared with those classed as having other disease $(\mathrm{P}=0.0001)$. There were no significant differences between those classed as definitely having the disease and those classed as probably having the disease $(P=0.1)$. No differences that were related to the sex of the patient were found.

The best results for sensitivity and specificity were obtained at the cut off point of $213 \mathrm{pg} / \mathrm{ml}$ (Youden Index 0.59). The receiver operating characteristics curve is shown in figure 2. The combined group and the group of those classed as having other diseases were used to calculate sensitivity and specificity. Sensitivity at $213 \mathrm{pg} / \mathrm{ml}$ was $77.8 \%$ (95\% confidence interval $68.8 \%$ to $85.2 \%$ ). Specificity at this value was $81.1 \%$ $(70.3 \%$ to $89.3 \%)$. The positive predictive value was $85.7 \%(77.2 \%$ to $92 \%)$ and the negative predictive value was $71.4 \%(60.5 \%$ to $80.8 \%)$. Applying the same cut off point to the control group gave a specificity of $85.9 \%$ $(69.0 \%$ to $94.6 \%)$.

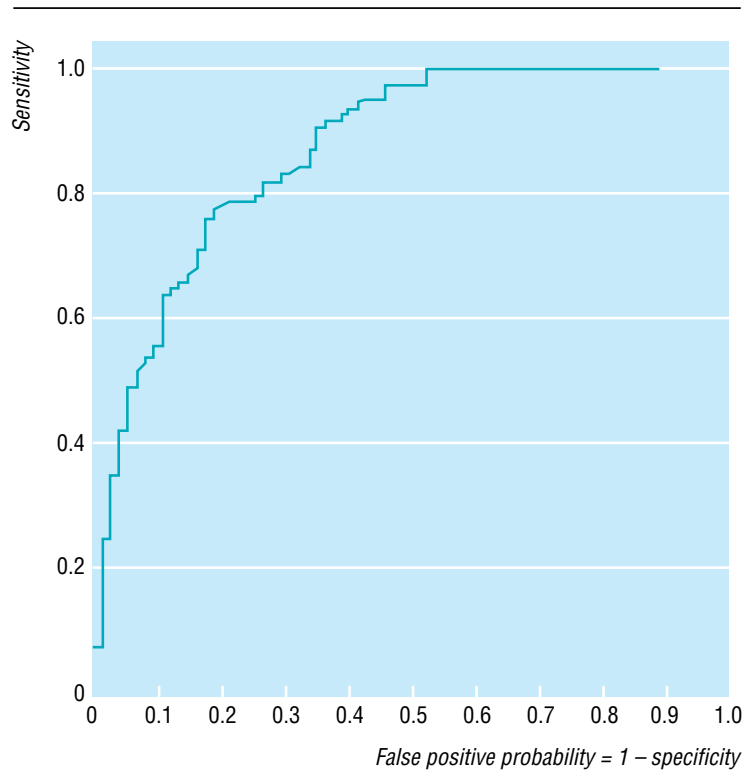

Fig 2 Curve of receiver operating characteristics at different cut off points of serum concentration of S100 protein

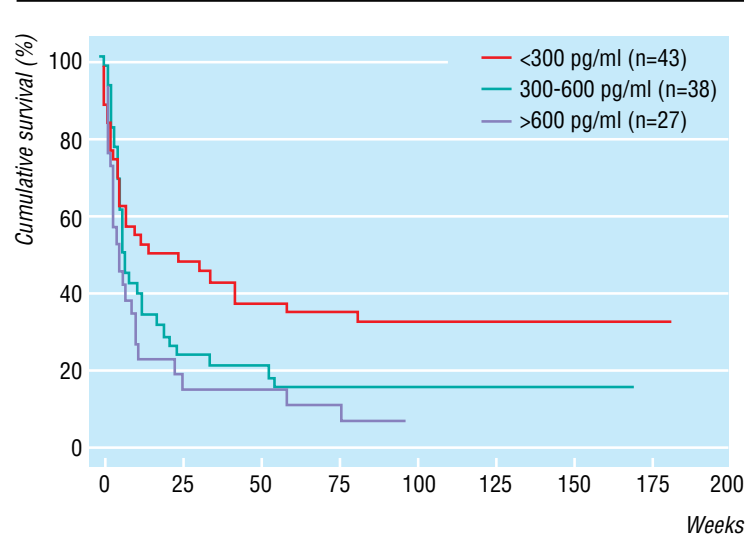

Fig 3 Kaplan-Meier survival curves at different serum concentrations of $\mathrm{S} 100$ protein $(\mathrm{P}=0.023)$

Fourteen of the 17 patients who were initially classed as possibly having the disease and whose disease was later confirmed neuropathologically had concentrations of $\mathrm{S} 100$ protein $>213 \mathrm{pg} / \mathrm{ml}$. Another two patients who were initially classed as having other disease and later reclassified as probably or definitely having the disease had concentrations $>213 \mathrm{pg} / \mathrm{ml}$. There were significant differences in the Kaplan-Meier survival curves plotted for different serum concentrations of S100 (fig 3) $(\mathrm{P}=0.023)$. Patients with fatal familial insomnia had concentrations of $<20 \mathrm{pg} / \mathrm{ml}$ and $22 \mathrm{pg} / \mathrm{ml}$. The serum concentration of S100 in the patient with an insert mutation was $178 \mathrm{pg} / \mathrm{ml}$. The patient with Gerstmann-Sträussler-Scheinker disease had a serum concentration of $1434 \mathrm{pg} / \mathrm{ml}$. The two patients with mutations at V210I had serum concentrations of $296 \mathrm{pg} / \mathrm{ml}$ and $757 \mathrm{pg} / \mathrm{ml}$.

\section{Discussion}

We have identified raised concentrations of a biochemical marker, S100 protein, in the serum of patients with Creutzfeldt-Jakob disease. Previously, diagnosis of the disease had been difficult because no biochemical marker had been identified in serum. We have obtained sensitivity of $77.8 \%$ and specificity of $81.1 \%$ at a cut off point of $213 \mathrm{pg} / \mathrm{ml}$. Serum concentrations of $\mathrm{S} 100$ in the group of patients classed as definitely or probably having the disease were significantly different from concentrations in the other patients.

The primary use of this test will be in the differential diagnosis of diseases which cause dementia. Raised serum concentrations of $\mathrm{S} 100$ protein are found in acute and subacute neurological diseases such as stroke, subarachnoid haemorrhage, and hypoxia causing brain damage ${ }^{16}{ }^{17}$; however, these diseases are usually excluded by cerebral computed tomography or magnetic resonance imaging. We found high concentrations of S100 in a patient with multiple sclerosis and in two patients with subacute meningoencephalitis (table 4). These diseases can be differentiated from the diagnosis of Creutzfeldt-Jakob disease by magnetic resonance imaging or lumbar puncture. Raised concentrations of S100 were also found in 14 out of 17 patients initially classed as possibly having CreutzfeldtJakob disease but reclassified as definite cases after 
neuropathological examination. Two out of three patients initially classed as having other disease also had raised concentrations of S100 and were later reclassified as definitely or probably having the disease. Measuring concentrations of S100 protein in serum may aid early diagnosis of Creutzfeldt-Jakob disease, at least until more specific tests are available. Specificity was acceptable when the cut off point of $213 \mathrm{pg} / \mathrm{ml}$ was applied to the control group of patients without dementia. However, this test must be evaluated on a larger group of patients who do not have dementia.

The serum test for S100 does not have the same sensitivity and specificity for the diagnosis of Creutzfeldt-Jakob disease as tests on cerebrospinal fluid..$^{811}$ In a smaller study of patients with Creutzfeldt-Jakob disease an immunoblot assay for 14-3-3 protein in cerebrospinal fluid had 98\% sensitivity and $99 \%$ specificity. ${ }^{25}$ However, other studies using this assay reported more false negatives. ${ }^{1326}$ A single measurement of serum concentrations of S100 will not replace a single measurement of proteins in cerebrospinal fluid, but repeated measurement of S100 over intervals of several days may improve diagnostic accuracy. It remains to be seen whether an analysis which combines results from tests on cerebrospinal fluid with results from serum tests would be more useful.

There are significant differences in survival associated with the serum concentration of S100; these differences are shown by the Kaplan-Meier curves. The differences support the hypothesis that serum concentrations of S100 increase during the course of the disease and the quantitative value may provide information about disease progression. Data from serial tests may provide verification of this; there could be alternative explanations for our findings such as that the disease may progress faster in patients with raised concentrations of $\mathrm{S} 100$.

A serum test for Creutzfeldt-Jakob disease is preferable to analysis of cerebrospinal fluid. Because of the short biological half life of S100 (2 hours) ${ }^{18}$ raised serum concentrations will decrease rapidly in cases of subarachnoid haemorrhage $^{16}$ and circulatory arrest during heart surgery, ${ }^{27}$ but concentrations of S100 will not fall during the course of Creutzfeldt-Jakob disease because of activation of the astroglia. Thus, acute diseases in which serum S100 concentrations rise can easily be excluded from the differential diagnosis by the transience of the rise. Additionally, because of the high homology between human and bovine $\mathrm{S} 100^{28}$ the serum test may also be used to diagnose bovine spongiform encephalopathy when there are no clinical signs of the disease.

We thank Professor K Felgenhauer, department head, for encouraging us to do this work. We also thank the physicians who made site visits to the hospitals in the study: A Szudra, S Räcker, S Grosche, M Lantsch, W Murach, K Weidehaas, and C Riedemann. We thank M Bodemer, M Liebeskind, and Professor M Oellerich for technical assistance. We also thank B J Steinhoff, assistant professor, for re-evaluating the electroencephalograms. Parts of this work, especially the follow up of patients classified as having other disease, are based on a thesis by B Mollenhauer. We thank all physicians who reported suspected cases of Creutzfeldt-Jakob disease to the German CreutzfeldtJakob disease surveillance unit for providing clinical, neuroradiological, and biochemical data as well as for their help in obtaining serum samples. LIA-mat Sangtec100 kits were provided by Byk Sangtec, Dietzenbach, Germany.
- Creutzfeldt-Jakob disease is a rare, fatal neurodegenerative disease. Diagnosis is made clinically and neuropathologically

- There is no serum test which allows the diagnosis to be made while the patient is alive

- In this study raised serum concentrations of S100 protein were found in patients with Creutzfeldt-Jakob disease

- Serum concentrations of S100 could be used with a sensitivity of $77.8 \%$ and a specificity of $81.1 \%$ to confirm Creutzfeldt-Jakob disease in the differential diagnosis of diseases that cause dementia

- Serial measurement of S100 concentrations will enhance diagnostic accuracy

Contributors: $\mathrm{MO}$ and JW had the original idea for measuring S100. MO,JW, and MU worked together to try to develop the ultrasensitive assay; this was later finalised using a different method with contributions from ES. IZ and AO participated in collecting data and were particularly involved in ensuring the correct documentation of clinical neurological data. Calculations and statistical interpretations were done by $\mathrm{OG}, \mathrm{AP}$, and MO. Neuropathological data was provided by AG, and HAK. TW worked in the same line of research and initiated the collection of samples from patients with SP and Professor Felgenhauer. Core ideas were discussed with and research supervised by SP. MO, JW, and SP are guarantors for the paper.

Funding: This study was supported in part by a grant from the Bundesministerium für Gesundheit and by a grant from the VerUm Stiftung

Conflict of interest: None.

1 Brown P, Gibbs CJJ, Rodgers-Johnson P, Asher DM, Sulima MP, Bacote A, et al. Human spongiform encephalopathy: the National Institutes of Health series of 300 cases of experimentally transmitted disease. Ann Neurol 1994;35:513-29.

Alperovitch A, Brown P, Weber T, Pocchiari M, Hofman A, Will RG. The incidence of Creutzfeldt-Jakob disease in Europe in 1993. Lancet 1994:334:918.

3 Kretzschmar H, Ironside J, DeArmond S, Tateishi J. Diagnostic criteria for sporadic Creutzfeldt-Jakob disease. Arch Neurol 1996;53:913-20.

4 Hill AF, Zeidler M, Ironside J, Collinge J. Diagnosis of new variant Creutzfeldt-Jakob disease by tonsil biopsy. Lancet 1997;349:99-100.

5 Masters CL, Harris JO, Gajdusek DC, Gibbs CJJ, Bernoulli C, Asher DM. Creutzfeldt-Jakob disease: patterns of worldwide occurrence and the significance of familial and sporadic clustering. Ann Neurol 1979;5:177-88.

6 Steinhoff BJ, Räcker S, Herrendorf G, Poser S, Grosche S, Zerr I, et al. Accuracy and reliability of periodic sharp wave complexes in CreutzfeldtJakob disease. Arch Neurol 1996;53:162-6.

7 Jimi T, Wakayama Y, Shibuya S, Nakata H, Tomaru T, Takahashi Y, et al. High levels of nervous system-specific proteins in cerebrospinal fluid in patients with early stage Creutzfeldt-Jakob disease. Clin Chim Acta 1992;211:37-46.

8 Zerr I, Bodemer M, Räcker S, Grosche S, Poser S, Kretzschmar HA, et al. Cerebrospinal fluid concentration of neuron-specific enolase in diagnosis of Creutzfeldt-Jakob disease. Lancet 1995;345:1609-10.

9 Otto M, Stein H, Szudra A, Zerr I, Bodemer M, Gefeller O, et al. S-100 protein concentrations in the cerebrospinal fluid of patients with Creutzfeldt-Jakob disease. J Neurol 1997;244:566-70.

10 Otto M, Wiltfang J, Tumani H, Zerr I, Lantsch M, Kornhuber J, et al. Elevated levels of tau-protein in cerebrospinal fluid of patients with Creutzfeldt-Jakob disease. Neurosci Lett 1997;225:210-2.

11 Hsich G, Kenney K, Gibbs CJ, Lee KH, Harrington MG. The 14-3-3 brain protein in cerebrospinal fluid as a marker for transmissible spongiform encephalopathies. N Engl J Med 1996;335:924-30.

12 Zerr I, Bodemer M, Otto M, Poser S, Windl O, Kretzschmar H, et al. Diagnosis of Creutzfeldt-Jakob disease by two dimensional gel electrophoresis of cerebrospinal fluid. Lancet 1996;348:846-9.

13 Will RG, Zeidler M, Brown P, Harrington M, Lee KH, Kenney KL. Cerebrospinal-fluid test for new variant Creutzfeldt-Jakob disease. Lancet 1996;348:955.

14 Isobe T, Takahashi K, Okuyama T. S100a0 (alpha alpha) protein is present in neurons of the central and peripheral nervous system. J Neurochem 1984;43:1494-6.

15 Kindblom L-G, Lodding P, Rosengren L, Baudier J, Haglid K. S-100 protein in melanocytic tumors. Acta Pathol Microbiol Immunol Scand 1984;92:219-30. 
16 Persson L, Hardemark HG, Gustafsson G, Rundstrom G, Mendel-Hartvig I, Esscher T, et al. S100 protein and neuron-specific enolase in cerebrospinal fluid and serum: marker of cell damage in human central nervous pinal fluid and serum: marker

17 Ingebrichtsen T, Romner B, Kongstad P, Langbakk B. Increased serum levels of protein S100 after minor head injury: a biochemical serum marker with prognostic value? J Neurol Neurosurg Psychiatry 1995;59:103-4.

18 Usui A, Kato K, Abe T, Murase M, Tanaka M, Takeuchi E. S100a0 protein in blood and urine during open heart surgery. Clin Chem 1989:35:1942-4

19 Weber T, Poser S, Zerr I, Räcker S, Behring B, Bogumil T, et al. Epidemiology and early diagnosis of human prion diseases. J Neurol 1995; 242:257

20 Will RG. Epidemiology of Creutzfeldt-Jakob disease. Br Med Bull 1993;49:960-70.

21 Windl O, Dempster M, Estibeiro JP, Lathe R, de Silva R, Esmonde T, et al. Genetic basis of Creutzfeldt-Jakob disease in the United Kingdom: a systematic analysis of predisposing mutations and allelic variation in the PRNP gene. Hum Genet 1996;98:259-64.
22 Vollset SE. Confidence intervals for a binominal proportion. Stat Med 1993;12:809-24.

23 Youden WJ. Index rating for diagnostic tests. Cancer 1950;3:32-5.

$24 \mathrm{Metz}$ CE. Basic principles of ROC analysis. Semin Nucl Med 1978;8:283-98.

25 Lee KH, Harrington MG. Premortem diagnosis of Creutzfeldt-Jakob disease by cerebrospinal fluid diagnosis. Lancet 1996;348:887.

26 Moussavian M, Potolicchio S, Jones R. The 14-3-3 brain protein and transmissible spongiform encephalopathy. N Engl J Med 1997;336:873-4

27 Astudillo R, Van der Linden J, Radegran K, Hansson L-O, Aberg B. Elevated serum levels of S100 after deep hypothermic arrest correlate with duration of circulatory arrest. Eur J Cardiothorac Surg 1996;10:110713 .

28 Jensen R, Marshak DR, Anderson C, Lukas TJ, Watterson DM. Characterization of human brain $\mathrm{S} 100$ protein fraction: amino acid sequence of S100 beta. J Neurochem 1985;45:700-5.

(Accepted 28 October 1997)

\title{
Slater revisited: 6 year follow up study of patients with medically unexplained motor symptoms
}

\author{
Helen L Crimlisk, Kailash Bhatia, Helen Cope, Anthony David, C David Marsden, Maria A Ron
}

\section{See editorial by \\ O'Brien \\ Institute of \\ Neurology, London \\ WC1N 3BG \\ Helen L Crimlisk, \\ research fellow \\ Kailash Bhatia, \\ senior lecturer \\ C David Marsden, \\ professor of neurology \\ Maria A Ron, \\ professor of \\ neuropsychiatry \\ Institute of \\ Psychiatry, London \\ SE5 8AF \\ Helen Cope, \\ senior lecturer \\ Anthony David, \\ professor of cognitive \\ neuropsychiatry \\ Correspondence to: \\ Professor Ron \\ M.RON@ion. \\ ucl.ac.uk}

BMJ 1998;316:582-6

\begin{abstract}
Objective: To investigate psychiatric and neurological morbidity, diagnostic stability, and indicators of prognosis in patients previously identified as having medically unexplained motor symptoms.

Design: Follow up study.

Setting: National Hospital for Neurology and Neurosurgery, London-a secondary and tertiary referral hospital for neurological disorders.

Subjects: 73 patients with medically unexplained motor symptoms admitted consecutively in 1989-91. $35(48 \%)$ patients had absence of motor function (for example, hemiplegia) and 38 (52\%) had abnormal motor activity (for example, tremor, dystonia, or ataxia).
\end{abstract}

Main outcome measures: Neurological clinical diagnosis at face to face reassessment by a neurologist and a psychiatric diagnosis after a standardised assessment interview - the schedule for affective disorders and schizophrenia-conducted by a psychiatrist.

Results: Good follow up data were available for 64 subjects (88\%). Only three subjects had new organic neurological disorders at follow up that fully or partly explained their previous symptoms. 44/59 (75\%) subjects had had psychiatric disorders; in 33 (75\%) patients, the psychiatric diagnosis coincided with their unexplained motor symptoms. 31/59 (45\%) patients had a personality disorder. Three subjects had developed new psychiatric illnesses at follow up, but in only one did the diagnosis account for the previous motor symptoms. Resolution of physical symptoms was associated with short length of symptoms, comorbid psychiatric disorder, and a change in marital status during follow up.

Conclusions: Unlike Slater's study of 1965, a low incidence of physical or psychiatric diagnoses which explained these patients' symptoms or disability was found. However, a high level of psychiatric comorbidity existed.

\section{Introduction}

In 1965 Elliott Slater published a highly influential study in the British Medical Journal that described a 10 year follow up study of patients admitted to the National Hospital for Nervous Diseases with a diagnosis of "hysteria." $2 \mathrm{He}$ found that over half of the patients developed clear cut neurological or psychiatric conditions during follow up. Since the 1960s several studies investigating the subsequent incidence of neurological disorder in patients with a diagnosis of "hysteria" or "conversion disorder" have been published, and rates of up to $25 \%$ have been reported. ${ }^{3-8}$ The proportion of patients whose symptoms are not adequately explained in physical terms and who are being cared for by British neurologists ranges from $20 \%$ to $40 \%{ }^{9}{ }^{10}$ Both neurologists and psychiatrists are therefore cautious about making a firm diagnosis in this group of patients. ${ }^{11}$

Thirty years after Slater's work, we carried out a follow up study on a similar population of patients. We attempted to avoid some of the methodological problems of previous studies. Our subjects were a consecutive series with unexplained motor symptoms, admitted between 1989 and 1991 to the National Hospital for Neurology and Neurosurgery, London (formerly the National Hospital for Nervous Diseases). All the patients had been thoroughly investigated with modern diagnostic techniques and all were eligible for inclusion, not only those who had been referred to a psychiatrist. Outcome was assessed on the basis of face to face neurological and psychiatric examination and scrutiny of all available medical records. Standardised instruments were used to ascertain the presence of psychiatric disorder.

\section{Methods}

Hospital discharge summaries of all patients aged 18-70 years who had been admitted between 1989 and 1991 were reviewed. We identified 73 consecutive sub- 